\title{
On the biomechanical properties of osteosarcoma cells and their environment
}

\author{
DANIEL A. MÜLLER ${ }^{1}$ and UNAI SILVAN*,1 \\ Biomechanics Laboratory, University Hospital Balgrist, University of Zürich, Zürich, Switzerland
}

\begin{abstract}
Although rare among the general population, bone malignancies have a high rate of incidence among children and adolescents and are associated with high mortality rates. Osteosarcoma (also known as osteogenic sarcoma) is the most frequent primary cancer of bone and shows a high tendency to metastasize to the lung. Despite the frequent use of osteosarcoma-derived cell lines in basic biomechanical research and for the evaluation of cell responses to new biomaterials, the mechanical phenotype and the differences between osteosarcoma cells and related cell types, such as mesenchymal cells, osteoblasts and osteocytes, remain largely unknown. In the present review we summarize current knowledge of the biophysical and mechanical properties of the niche of primary osteosarcomas and of the malignant cells, and discuss the impact of these features on the progression of malignancy.
\end{abstract}

KEY WORDS: osteosarcoma, bone cancer, biomechanics, stiffness, mesenchymal stem cell

\section{Introduction}

Osteosarcoma is the most frequent malignant cancer of the skeleton and displays a bimodal age distribution with most cases being diagnosed during the second decade of their life and a second highest incidence peak in adults over 40 (Jo and Fletcher, 2014). A remarkable characteristic of this malignancy is its high tendency to metastasize in the lungs via hematogenous route. Approximately $20 \%$ of patients exhibit radiologically detectable lung metastases at diagnosis and nearly all of them have microscopic lesions that become evident during the course of the disease (Ross et al., 1999). Although the 5-year-survival rate of people with localized osteosarcoma has improved significantly over the last decades and is currently in the range of $60 \%$ to $80 \%$, the prognosis for those displaying detectable secondary lesions at diagnosis is much worse, as their rate after 5 years of diagnosis is only 15 to $30 \%$ (Gorlick and Khanna, 2010; Mirabello et al., 2009).

A number of factors, including radiation, trauma, genetic predisposition and rapid bone growth have been suggested as possible etiologic factors of osteosarcoma (Ottaviani and Jaffe, 2009), however the cause and cell-of-origin of these tumors still remains unclear. The presence of different histologic forms of osteosarcoma points to a cell type with potential for pluripotent differentiation. This, along with the high incidence of osteosarcoma in growing children and their anatomic location within the metaphysis of long bones, where mesenchymal stem cells (MSCs) reside, supports the role of this population as 'tumor initiating cell' (Mutsaers and Walkley, 2014). Nevertheless, there is evidence to suggest more committed pre-osteoblastic cells that retain some differentiation potential as the origin of osteosarcomas. For instance, gene alterations that are known to promote bone malignancies, such as mutations in the $P 53$ and retinoblastoma $(R B)$ genes (Gorlick and Khanna, 2010), result in higher tumor incidence when the genetically modified cells express osteoblastic markers, such as osterix-1 (OSX) or osteocalcin (OCN) (Mutsaers and Walkley, 2014).

During tumor development and progression cancer cells acquire genetic and epigenetic modifications that render them more competent in the neoplastic microenvironment and are therefore transferred to subsequent cell generations (Martincorena et al., 2017). As a result of this selective pressure, those features that favor cancer cell survival and expansion are selected and give rise to the so-called 'malignant phenotype'. As these changes are to a great extent driven by the biomechanical constraints that cancer

\footnotetext{
Abbreviations used in this paper: AFM, atomic force microscope; ALP, alkaline phosphatase; BMP, bone morphogenetic protein; COX, cyclooxygenase; CSC, cancer stem cell; ECM, extracellular matrix; IL, interleukin; MSC, mesenchymal stem cell; NO, nitric oxide; OCN, osteocalcin; OPN, osteopontin; OSX, osterix-1; PAA, polyacrylamide; PGI2, prostacyclin; PTHrP, parathyroid hormone-related protein; RANKL, receptor activator of nuclear factor kappa-B ligand; RB, retinoblastoma; TAZ, transcriptional coactivator with PDZ-binding motif; TNF- $\alpha$, tumor necrosis factor; YAP, yes-associated protein.
}

*Address correspondence to: Unai Silvan. Universitätsklinik Balgrist, Forschung Biomechanik, Lengghalde 5, 8008 Zürich, Switzerland.

E-mail: unai.silvan@uzh.ch - iD https://orcid.org/0000-0003-0757-3621

Submitted: 24 January, 2019; Accepted: 13 February, 2019.

ISSN: Online 1696-3547, Print 0214-6282

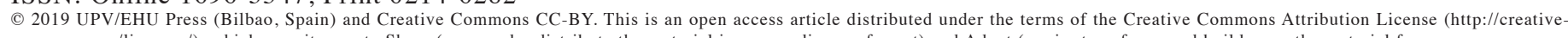

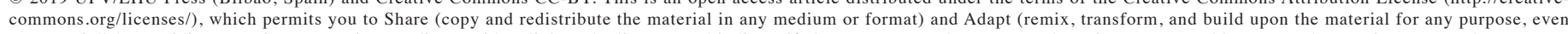

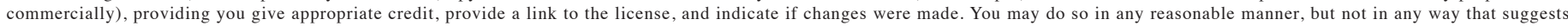
the licensor endorses you or your use. Printed in Spain 
cells withstand, the description of the biophysical properties of the malignant cells and their microenvironment offers a different insight into their capabilities and impact on neoplastic progression (Northcott et al., 2018).

\section{The physical microenvironment of osteosarcoma}

Most of the knowledge on the biophysical properties of the bone microenvironment has been derived from the development of implantable biomaterials. The biophysical properties of these implants, such as roughness, surface energy and stiffness, are among the most studied passive elements of the bone niche.

\section{Rugosity}

The impact of surface roughness $\left(R_{a}\right)$ on cell attachment has been studied using various cell types, including osteosarcoma-derived cells. In the case of MG-63 osteosarcoma cells highest levels of adhesion were found in surfaces with an $R_{a}$ value of $2.4 \mu \mathrm{m}$, being the attachment on smoother surfaces significantly reduced. The spreading area of osteosarcoma cells is also significantly affected by surface topography, with the cells on rough substrates being significantly smaller (Dowling etal., 2011). Interestingly, it has been reported that the reduction in projected area is more pronounced in primary osteoblasts, which decrease their surface by over $60 \%$ in substrates with an $\mathrm{R}_{\mathrm{a}}$ of $6.07 \mu \mathrm{m}$ compared to flat ones, than for MG-63 cells, for which the reduction represents only $20 \%$ (Lüthen et al., 2005). It has also been found that osteosarcoma cells that adhere to rough substrates upregulate their expression of $\alpha 5, \beta 1$ and particularly, $\beta 3$ integrins, and increase their basal alkaline phosphatase (ALP) activity and OCN expression, whereas their proliferative potential is reduced (Lincks et al., 1998; Lüthen et al., 2005).

Lohmann and colleagues (2000) compared the response of osteogenic cells to increasing differentiation on titanium surfaces with different rugosities and observed that the proliferation and expression of osteogenic markers of osteoblast-like cells and MSCs were less affected by surface texture than in the case of more mature osteocytes (Lohmann et al., 2000). In turn, MG-63 cells follow an intermediate program, in agreement with their moderate osteoblastic phenotype (Lincks et al., 1998; Martin et al., 1995). It should be noted that these observations are not limited to differentiation and alterations in other pathways caused by substrate topography, such as sensibility to a number of exogenous factors, have also been reported (Boyan et al., 2001). It is also important to remember that cellular response to these surface-guided effects is strongly influenced by biological factors such as the ligands that are used to coat the surfaces prior to cell attachment. For instance, it was shown that when using calcium phosphate hydroxyapatite substrates, which have a similar composition as bones, MSCs preferentially attach to them when previously coated with collagen-I instead of fibronectin. However, osteosarcoma cell lines, such as SaOs-2 and MG-63 have the apposite tendency (Vohra et al., 2008).

Among topography-driven cell behaviors, contact guidance refers to the likelihood of cultured cells to align along geometrical features such as grooves or fibers, and is a common characteristic of eukaryotic cells, including osteoblasts (Lenhert et al., 2005). The 'orientation parameter' $\left(\alpha_{\text {inf }}\right)$ is an indication of the susceptibility of cells to align along grooved substrates independently of the experimental conditions. For primary osteoblasts, this value is close to $0^{\circ}$, indicating complete alignment of the cells. On the other hand, the reported $\alpha_{\text {inf }}$ value for osteosarcoma SaOs-2 cells is $23^{\circ}$, which implies that these cells have partially lost their contact guidance feature (Davidson et al., 2015). However, when performing an orientation analysis of the nuclei of the same cells, it was observed that the nuclei of SaOs-2 display orientations similar to those of the cell body, even on non-patterned substrates, while in osteoblasts, this correlation does not exist in either case (Davidson et al., 2015).

\section{Wettability}

Topography and chemical properties define the wettability of a surface, which can be expressed as the contact angle $(\theta)$ of a water droplet resting on it, and corresponding low values to hydrophobic and large ones to hydrophilic surfaces. It has been reported that SaOs- 2 cells adhering to a surface with a $\theta$ of $44^{\circ}$ display smaller spreading areas, lower proliferation, and higher ALP activity than when cultured on substrates with $84^{\circ}$ and $34^{\circ}$ water contact angles (Jirka et al., 2017). Although with slightly different $\theta$ values, MG-63 cells respond similarly to surface wettability and attach preferentially to polystyrene surfaces with $\theta$ values of approximately $64^{\circ}$ (Dowling et al., 2011). Interestingly, primary human MSCs that grow on stiff silicone substrates doped with poly (dimethylsiloxane-ethylene oxide) (PEO) surfactant and have a $\theta$ value in the same range $\left(60^{\circ}\right)$, display a tendency of osteogenic differentiation (Razafiarison et al., 2016). Although the regulatory mechanism is not fully understood, a plausible explanation is the hydrophobicity-driven exposure of cell binding sites in the deposited extracellular matrix (ECM), collagen I in this case, which in turn directs the expression of focal adhesion components (Razafiarison et al., 2018).

\section{Stiffness}

In general, tumor cells are known to cause the stiffening of the surrounding tissue due to an increased deposition of ECM proteins and crosslinking of these through secreted factors (Lu et al., 2012). As osteosarcomas arise in the hardest tissue of the body the dogma that states that solid tumors are macroscopically harder than the healthy tissue from which they originate does not apply in this case. By using osteosarcoma-affected canine antebrachia, it was shown that these tissues are markedly weaker and more compliant, exhibiting a step-by-step reduction in load after reaching maximum load, indicative of sequential structural failures (Steffey et al., 2017). A number of non-exclusive mechanisms have been described as cause of bone tissue softening. Firstly, as it happens in many tumor types, osteosarcoma cells are known to secrete enzymes that lead to the decomposition of the main components of the tissue (Bjørnland et al., 2005). On the other hand, the formation of distant metastases is associated with the presence of osteoclasts in the biopsies of the primary malignancy. These monocyte-derived cells are responsible for bone degradation in physiological conditions, and it has been shown that osteosarcoma cells can also regulate their activity by releasing soluble growth factors, including nuclear factor kappa-B ligand (RANKL), tumor necrosis factor- $\alpha$ (TNF- $\alpha$ ) and interleukin-11 (IL-11) (Avnet et al., 2008; Verrecchia and Rédini, 2018). Furthermore, osteosarcoma cells are known to regulate the production of factors, such as bone morphogenetic proteins (BMPs) or parathyroid hormone-related proteins (PTHrP), which drive the production of RANKL by osteoblasts, thereby increasing osteoclast activity. Furthermore, there is 
Fig. 1. Impact of substrate stiffness on osteosarcoma spreading and aggregation. (A) Independently of the cell adhesive motif used (Fibronectin orRGD peptide), U2OS cells form multicellular aggregates when cultured on soft substrates 10.5 and $4.5 \mathrm{kPa}$ ) and display a spread morphology on stiffer ones (10 and $40 \mathrm{kPa}$ ). (B) Similar phenotypic changes are observed in MG-63 cells adhering for 4 days to hydrogelss of different stiffnesses coated with collagen I. Scale bar represents $100 \mu \mathrm{m}$.
A
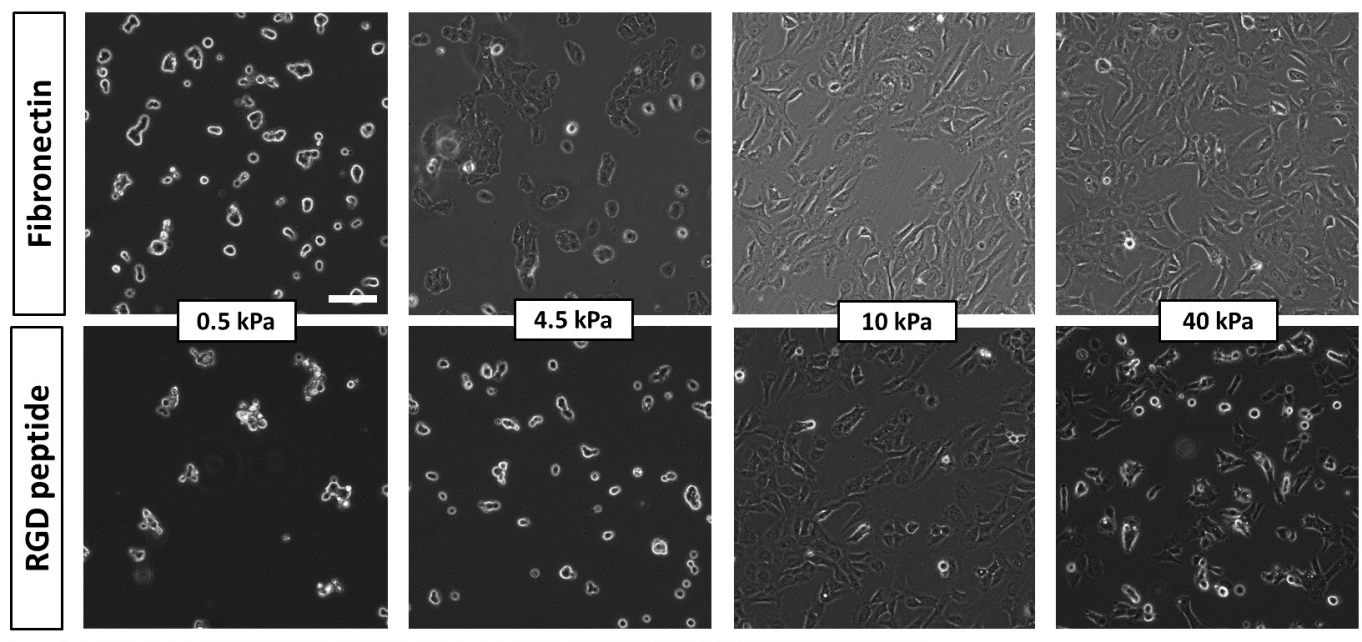

B
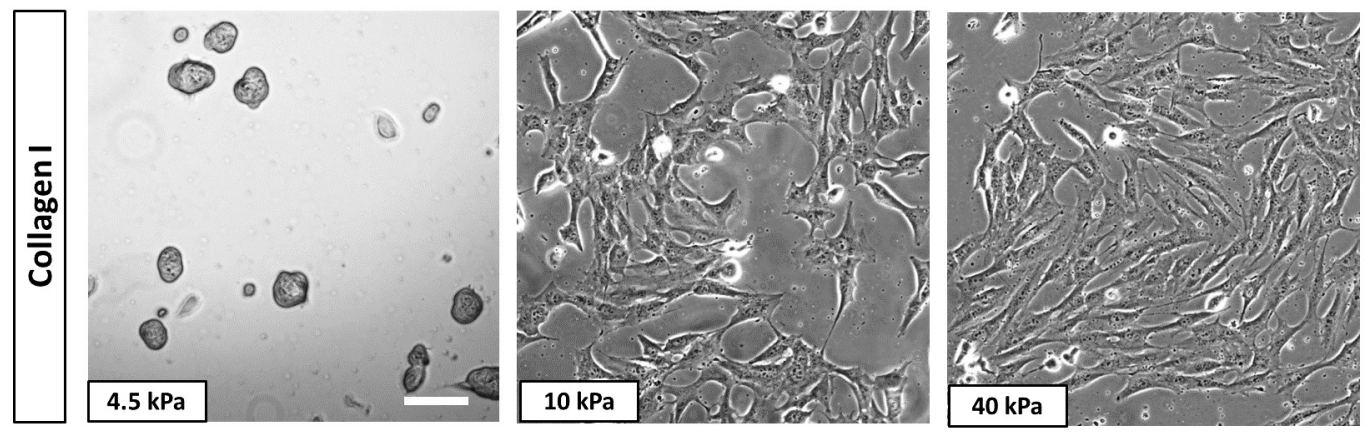

evidence of the mechanoregulated secretion galectin-3, a member of the $\beta$-galactoside binding lectin family. While in adherent state cancer cells secrete low levels of galectin-3 into the medium, once the cells acquire rounded shapes, the concentration increases significantly (Baptiste et al., 2007). In addition to its impact in integrin clustering and activation, galectin-3 is considered a negative regulator of bone formation (Zhou et al., 2014; lacobini et al., 2017), and it is likely that high levels of galectin-3 exacerbate the softening of the tissue concomitant to osteosarcoma progression (Maupin et al., 2018).

As we will discuss later, the ability of cells to probe their mechanical microenvironment depends on the generation and transmission of oscillating pulling forces through the actin cytoskeleton and adhesion complexes that connect the cytoskeleton to the ECM. It is known that changes in ECM stiffness provoke different degrees of cell spreading, which in turn determines the tension transmitted to the actin cytoskeleton. In this context, YAP (yes-associated protein) and TAZ (transcriptional co-activator with PDZ-binding motif), the main transcriptional effectors of the Hippo signaling pathway, are known to shuttle from the cytoplasm to the nucleus in cells adhering to stiff substrates and when the spreading area is limited (Dupont et al., 2011). Although the precise mechanism by which these transcription factors activate is not completely understood, it seems clear that cytoskeletal tension and GTPase Rho are needed for this purpose. The implications of this regulatory mechanism drive MSC differentiation towards cell lineages that reside in tissues that posses similar mechanical properties (Engler et al., 2006). For instance, MSCs adhering to soft surfaces tend to be neurogenic while, on stiffer substrates, they activate myogenic or osteogenic differentiation programs. The tissue in which cancer arises also defines the stiffness at which the so-called cancer stem cells (CSCs) propagate faster. For instance, while breast CSCs prefer gels displaying a Young's modulus (E) of $5 \mathrm{kPa}$, U2OS osteosarcoma cells proliferate and retain their stemness better when adhering to 50 kPa gels (Jabbari et al., 2015). Similarly, Mylona and colleagues (2008) analyzed the effect of substrates with $E$ values of 1,7 , and $55 \mathrm{kPa}$ on primary osteosarcoma cells and observed an increase in the number of apoptotic cells on soft substrates, with the survival rate of cells on $55 \mathrm{kPa}$ polyacrylamide gels and glass (E>50 GPa) being the highest (Mylona et al., 2008). In a similar study in which the response of MG-63 cells was compared with that of a neuroblastoma cell line on softer substrates with $E$ values in the 0.3 to $12 \mathrm{kPa}$ range, it was revealed that, depending on surface rigidity, the phenotype of osteosarcoma cultures shifts between well-spread monolayers on substrates with an $E$ modulus higher than that of the cells and multi-cell spheroid-like aggregates when growing on substrates with stiffness values below that threshold (Pak et al., 2015) (Fig. 1). However, neuroblastoma-derived cells did not exhibit the same behavior, and no equivalent phenotypic shift was observed (Pak et al., 2015).

\section{Forces acting on bone resident cells}

More than 30 years ago, Frost hypothesized the mechanical regulation of bone remodeling and named it 'mechanostat' (Frost, 1987). According to this principle, depending on the magnitude, range, duration, and frequency of the load to which bone is exposed, different biological programs are triggered. While underloaded bones reduce their mass and strength, overload results in the reinforcement of the tissue, and under intermediate mechanical 
stress, bone mass and strength remain constant (Frost, 2003). Since this hypothesis was first proposed several biomechanical stimuli driving this adaptation have been discovered (Fig. 2).

\section{Shear stress}

Although compressive forces are the most obvious stresses acting on bone, these are actually transmitted to osteocytes as microscale shear forces, which result from the movement of the interstitial fluid within the lacuno-canalicular network. Shortly after exposure to these shear forces, the cytoplasmic levels of calcium in the resident osteocytes increase, and these cells activate cellular programs that potentiate bone formation and remodeling by stimulating the neighboring osteocytes and osteoblasts through gap-junctions and paracrine signaling (Wittkowske et al., 2016). The oscillatory nature of the flow profile experienced in their natural environment is known to affect these cells in a different manner than unidirectional shear stresses. For instance, it has been observed that after 24 hours under oscillatory flow regimes (11 dyn/cm², $0.5 \mathrm{~Hz}$ ), MLO-Y4 osteocytes display more elongated shapes, form numerous dendrites, and upregulate the expression of cyclooxygenase (COX), not existing such responses in cells under unidirectional shear regimes of similar magnitude (8 dyn/ $\mathrm{cm}^{2}$ ) (Ponik et al., 2007).

MC3T3-E1 osteoblasts have been reported to respond to fluid stress in the range of $12 \mathrm{dyn} / \mathrm{cm}^{2}$ by reorganizing their actin cytoskeleton into stress fibers and recruiting $\beta 1$ integrin and $\alpha$-actinin in the focal adhesions (Pavalko et al., 1998). These cytoskeletal changes seem to require a longer time to occur when osteoblasts are exposed to an oscillatory flow, being however the upregulation of $C O X$ and osteopontin (OPM) in both flow regimes, comparable (Ponik et al., 2007). Exposing normal human mandible-derived osteoblasts to shear stresses in the range of $20 \mathrm{dyn} / \mathrm{cm}^{2}$ for 30 minutes causes their proliferation and differentiation through Erk1/2 activation (Kapur et al., 2003). However, these experiments did not exclude the involvement of other pathways, particularly related to nitric oxide (NO) and prostaglandin production, with respect to the shear stress-response of osteoblasts. In fact, experiments using newborn rat calvarial osteoblasts revealed that fluid shear stress stimulates NO release through two distinct pathways, a G-protein and calcium-dependent phase, which is sensitive to flow transients, and a G-protein and calcium-independent pathway, which is stimulated by sustained flow (McAllister and Frangos, 1999).

\section{Compression}

Osteocytes also respond to direct compressive stimuli. For instance, the fully differentiated osteoblastic murine cell line MLO-A5 cultured in 3D scaffolds upregulates the expression of OPN and $O C N$ when exposed to a compressive loading regime consisting of $5 \%$ strain at $1 \mathrm{~Hz}$ for 2 hours every 5 days over a total time span of approximately three weeks (Sittichockechaiwut et al., 2009). Although apparently less sensitive, osteoblasts embedded in collagen gels exposed to a static compression of $2 \mathrm{~g} / \mathrm{cm}^{2}$ display a higher expression level of $O C N$ along with upregulated levels of the osteogenic marker RUNX2 and increased secretion of osteoclastic differentiation factors (Shen et al., 2017). Regimes with higher load values do not further enhance the expression of these osteogenic markers (Shen et al., 2017) and may ultimately produce the opposite effect. Using a bioreactor that applies compressive load by increasing the pressure of environmental gas up to $3 \mathrm{~atm}$ $\left(31 \mathrm{~g} / \mathrm{cm}^{2}\right)$, a significant reduction in ALP activity in osteoblasts was found. Furthermore, under these conditions, osteoblastic cells were shown to secrete paracrine factors that promote the undifferentiated state of neighboring cells (Ozawa et al., 1990). As undifferentiated tumors are more aggressive than those with a more mature phenotype, these observations suggest that the compressive load that bone malignancies experience in their primary site and the overload caused in the surrounding healthy tissue could negatively impact their progression. To analyze the effect of such mechanical stimuli on malignant cells a group of researchers used decellularized bone and bioengineered gels to test the effect of

Fig. 2. Biomechanics of premalignant (left) and malignant (right) osteosarcoma cells and their microenvironment. Unlike soft tissue neoplasms, osteosarcoma lesions are more compliant than the tissue in which they originate. This unique feature together with the loss of tissue architecture over malignant progression, provokes alterations in the mechanical stimuli

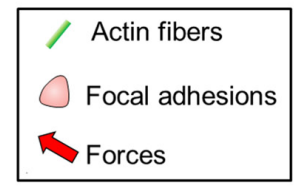
to which osteosarcoma cells are

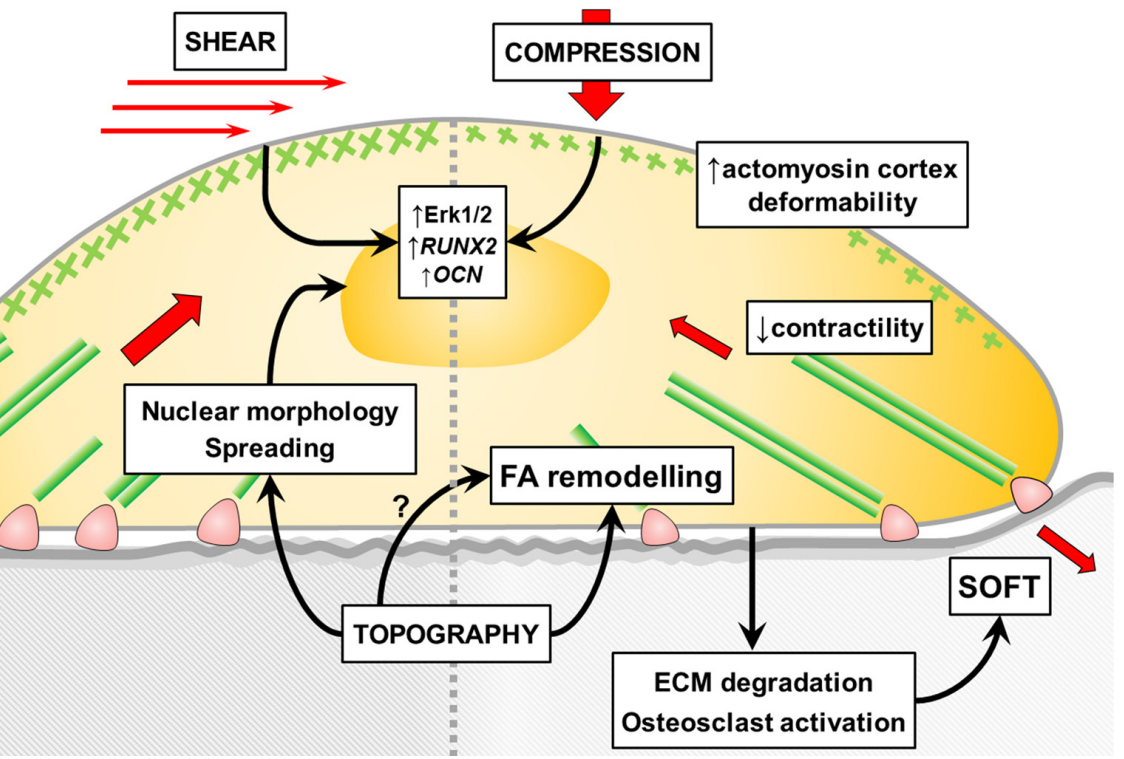

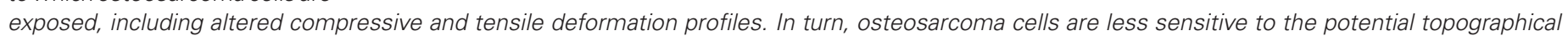

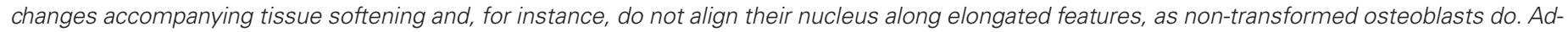

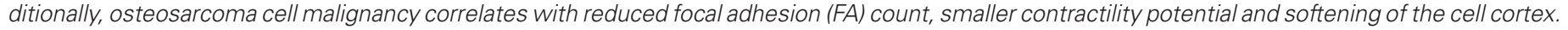


compressive mechanical loading on Ewing's sarcoma, the second form of bone cancer in terms of incidence (Marturano-Kruik et al., 2015; Marturano-Kruik et al., 2018). Their results reveal that under physiological load regimes Ewing's sarcoma cells rescue signaling pathways, including Erk1/2-Runx2 signaling, that promote tumor development and proliferation and confer chemoresistance to the cells. As many of these resistance pathways are shared among different tumor types, and considering the nearly identical stimuli that osteosarcoma cells experience in their primary site, this evidence should be considered while testing chemotherapeutic agents on this tumor type (Martin et al., 2011).

\section{Tensile stress}

Mechanical compression of bone is accompanied by elastic deformations, which cells sense as tensile strains. This mechanical stress is defined as $E=L_{0} / L$, with $L_{0}$ and $L$ being the initial length and length under tension, respectively. The resulting value has no units and can be noted as a percentage deformation or as microstrain $(\mu \mathrm{E})$, which is obtained by multiplying the change in length by $10^{6}$. While in vivo, bone mass has been reported to increase when strains are larger than $0.15 \%$, in vitro cells require larger deformations to activate their osteogenic program. A plausible explanation to this inconsistency is the underestimation of the physiological shear stresses occurring in the lacuno-canalicular network (Han et al., 2004). In this regard, a number of mathematical models have pointed out the ability of the the osteocyte physical environment to amplify the strain. For instance, it has been estimated that in their native environment osteocytes exposed to strains in the range of 3000 $\mu \mathrm{E}$ experience significantly higher deformations in their cell body with maximum values of over $20.000 \mu \mathrm{E}$ (Verbruggen et al., 2012).

Tensile stress is known to impact the differentiation of preosteoblasts through the BMP4-dependent activation of the Cbfa1/Osf-2 transcription factor (Ikegame et al., 2001). However, as it was the case for shear stress, the effect of tensile stress on differentiation seems to be dramatically affected by its magnitude. For instance, an analysis of the response to strains in the range of 0.8 to $3.2 \%$ revealed that ALP activity is highest in the lower range, but it significantly reduces for strains higher than $1.6 \%$. Similarly, healthy human primary osteoblasts showed that a stretching protocol consisting of $1000 \mu \mathrm{E}$ at $1 \mathrm{~Hz}$ for 1800 cycles for 2 days causes a significant increase in cell number, while ALP activity and osteocalcin release are reduced (Kaspar et al., 2000). More intense loading protocols (2500 $\mu \mathrm{E}$ at $0.5 \mathrm{~Hz}$ for 1 hour per day over a total timespan of 3 days) cause a similar increase in osteoblast cell division along with an upregulation of the expression of $\beta 1$ and $\beta 5$ integrins (Yan et al., 2012). siRNA experiments further revealed a link between these integrins and the upregulation of the Erk pathway (Yan et al., 2012).

Regarding osteosarcoma, SaOs-2 cells biaxially loaded at an average deformation of $5 \%$ for 24 hours increase their expression of TGF-b1, IGF-1, bFGF, and IL-6, with the levels of $I L-1 B$ remaining unaltered. This regulation can be interpreted as similar to that observed in osteoblasts, increasing the expression of bone growth factors, while leaving catabolic cytokine expression unaffected (Cillo et al., 2000). Similarly, ROS 17/2.8 rat osteosarcoma cells increase the activation of Erk-1/2, which is sustained for 24 hours, when subjected to a 10-minute period of cyclic tensile loading (Jessop et al., 2002). Further experiments in which the contribution of different pathways to this response pointed to calcium mobilization from intracellular stores and production of $\mathrm{NO}$ and prostacyclin
(PGI2) as central to the activation of Erk-1 (Jessop et al., 2002), being these pathways different to those triggered by shear stress.

\section{The biomechanical phenotype of osteosarcoma cells}

\section{Force generation}

The mechanism by which cells sense and respond to surface rigidity involves generation of oscillating pulling forces through cellsubstrate adhesions (Ghassemi et al., 2012). Methods to estimate these forces employ compliant substrates, such as polyacrylamide (PAA) gels or silicon-based surfaces, with fiducial markers, or flexible micropillar arrays to which cells adhere and deflect, to estimate traction forces (Goedecke et al., 2015; Holenstein et al., 2017). By using these methods, it was shown that cells adapt the force they generate to the apparent stiffness of the underlying substrates. For instance, MG-63 cells on soft PAA gels $(E=\sim 1 \mathrm{kPa})$ generate tractions below $0.5 \mathrm{kPa}$, whereas on $55 \mathrm{kPa}$ gels, magnitudes of over $2 \mathrm{kPa}$ were recorded (Mylona et al., 2008). It has been also reported that generated tractions correlate with differentiation state, being in case of undifferentiated MSCs the recorded mean values around $128 \mathrm{~Pa}, 200 \mathrm{~Pa}$ for MC3T3-E1 osteoblasts and over $350 \mathrm{~Pa}$ in case of the fully differentiated MLO-A5 osteocyte cell line when tested on 9.3 kPa PAA gels (Poellmann et al., 2015). With respect to malignant cells, a correlation between lower force generation capabilities and increased malignancy has been proposed for a number of tumor types, including breast, prostate and lung cancers (Kraning-Rush et al., 2012). Nevertheless, this trend seems to be the opposite in the case of osteosarcomas. In our laboratory, we used a semi-high-throughput method in which osteosarcoma cells attaching to silicone micropillar arrays were automatically imaged, and the deflections of the microposts quantified. The results showed that the experimentally selected highly metastatic HuO9-M132 cells cover fewer posts and generate significantly smaller forces, being the average force on each post also smaller (Goedecke et al., 2015). This result was recently confirmed and was extended to the SaOs-2/LM5 paired osteosarcoma cells using standard twodimensional TFM and micropost-based TFM (Holenstein et al., under review). The results of this experiments point to a gradual reduction in force generation from healthy osteoblasts as they adopt a malignant phenotype. The relationship between the decreased cellular tractions and the simultaneous softening of the tissue as the neoplasm develops is not common to other tumor types and may be of relevance in this and other bone tumors. This unique feature may also explain the previously discussed aggregation of osteosarcoma cells growing on soft surfaces (Pak et al., 2015).

\section{Mechanical properties in the adhering state}

The first attempt to mechanically characterize single osteosarcoma-derived cells was reported 1999 as a newly developed cytoindenter was used to test MG-63 cells and their average Young's modulus (E) was estimated to be nearly $2 \mathrm{kPa}$ (Shin and Athanasiou, 1999). Since then, the use of atomic force microscopy (AFM) for the mechanical characterization of biological tissues and cells has gained popularity, and up to date many research groups have used it to estimate the stiffness of osteosarcoma cells. Depending on the cell line being tested and on the experimental conditions, the obtained $\mathrm{E}$ values may vary between less than 1 and $4 \mathrm{kPa}$ (Bartalena et al., 2011; Wang et al., 2016). As cell indentation measurements are highly affected by underlying 
cytoplasmic structures such as the nucleus, organelles and stress fibers, this variability can be explained by the different cell regions tested in each study. For instance, probing U2OS osteosarcoma cells in the nuclear region (defined by the authors as parts of the cell higher than $1 \mu \mathrm{m}$ ) renders a mean elastic modulus of 2.8 $\mathrm{kPa}$, with the average stiffness of the peripheral region $(<1 \mu \mathrm{m})$ being $4.4 \mathrm{kPa}$ with peak values of $7.5 \mathrm{kPa}$ (Zhang et al., 2017). It should be noted that a significant softening of MG-63 cells during the telophase stage of the cell cycle has also been documented (Zhang et al., 2017), which exposes the importance of considering biological processes during the experimental design of studies on single cell mechanics. With respect to healthy bone cells in adhering state, Darling and colleagues (2008) reported an E value of $6.5 \mathrm{kPa}$ for the central region of osteoblasts and $3.2 \mathrm{kPa}$ for MSCs (Darling et al., 2008), suggesting cell body stiffening as a marker of osteoblastic differentiation. However, other authors found the opposite trend, depending again on the experimental conditions (Bongiorno et al., 2014). For instance, while human osteoblasts and osteosarcoma-derived MG-63 cells both display a $E$ value of approximately $1.5 \mathrm{kPa}$ when cultured on bare glass, on collagen l-coated surfaces the stiffness of the tumorigenic cells drops by nearly $50 \%$ remaining in case of osteoblasts unaltered (Docheva et al., 2008).

As previously mentioned, microindentation is highly affected by the mechanical properties of the nucleus. The biophysical properties of this organelle are conferred by a filamentous protein layer that lies beneath the nuclear envelope and has as main constituent lamin A/C. It is known that the amount of lamin A present in these networks increases with the stiffness of the tissue where cells are found, being in case of MSCs and bone cells highest (Swift et al., 2013). As previously discussed, an increased tendency to deform their nucleus and elongate it along the cell body axis was observed in SaOs-2 osteosarcoma cells over healthy osteoblasts (Davidson et al., 2015). In fact, when adhering to micropatterned surfaces containing micron-sized pillars at distances smaller than the size of the nucleus, all tested osteosarcoma cell lines, including MG-63, SaOs-2, and OHS4, display higher nuclear self-induced deformations than normal osteoblasts (Davidson et al., 2015). Apart from the potential use of this experimental approach in combination with automatic imaging and segmentation, for the estimation of cell malignancy (Ermis et al., 2016), the reduction in nuclear stiffness has also significant impact in the capabilities of cancer cells. For instance, it is known that in a number of cancer types, cell body and nuclear deformation act as factors that limit the invasion of stiff matrices (Chen et al., 2018).

\section{Mechanical properties in the free-floating state}

During their hematogenous metastatic dissemination, cancer cells adopt rounded shapes and are carried by the blood circulation. In this stage of cancer progression, the major biomechanical threats cancer cells have to overcome are shear stress and collision forces. Under these circumstances, the cell cortex, a network of proteins attached to the cytoplasmic side of the plasma membrane through anchoring proteins, acquires central importance in determining the biomechanical properties of the cell. The main component of the cortex is actin, which appears forming filaments crosslinked to each other by myosin II and other actin-binding proteins. Although the properties of rounded cells can be determined using AFM, the use of this tool renders a low throughput and high variability.
In turn, real time deformability cytometry (RT-DC) is a method for the characterization of non-adhering cells that makes use of microfluidics and high speed imaging to assess the mechanical phenotype of large cell populations (Otto et al., 2015). In a recent article, which made use of this tool, the deformability of skeletal stem cells (SSCs), an MSC population characterized by STRO-1 expression, and that of MG-63 osteosarcoma cells was shown to be similar (Xavier et al., 2016). However, when unselected MSCs populations were tested using the same technique, MSCs were found to be stiffer than both, osteosarcoma-derived cells and SSCs. In addition, a trend of increased deformability of experimentally selected highly metastatic osteosarcoma cells has as well been described recently (Holenstein et al., under review), pointing to changes in this mechanical property as a potential diagnostic and prognostic marker of circulating tumor cells in peripheral blood of osteosarcoma patients, as it has been proposed for other tumor types (Wu et al., 2016).

\section{Conclusions}

Although frequently used in basic biomechanical research and in the testing of implantable biomaterials as a model for bone cells, the biomechanical properties of osteosarcoma cells have rarely been compared with those of related cell types, such as osteoblasts or MSCs. Similarly, the comparison between the mechanical profile of healthy tissue and primary malignancy, as done for other neoplasms, is missing in the case of bone tumors. Therefore, drawing definitive conclusions about many of the aspects that have been discussed in this review is not possible. However, some biomechanical parameters follow a trend in independent studies or have been subject to comparative analysis, allowing us to outline the biomechanical malignant phenotype of these cells. For instance a gradual loss of the ability to sense environmental stiffness, as evidenced by a reduced response to surface roughness and lower force generations, seems to be associated with osteosarcoma malignancy. Additionally, cell body softening in free-floating state is characteristic of malignant transformation and of increased metastatic potential. As such cellular features affect the sensibility of bonce cancer cells to chemotherapeutic drugs these observations should be considered when testing treatment options in vitro.

\section{Acknowledgements}

This work was supported by the Kurt and Senta Herrmann Foundation and by the Swiss National Science Foundation (grant numbers 165670, 138221 and 118036). The authors wish to thank Prof. Jess G. Snedeker for his suggestions and fruitful discussions, and Dr. Adam A. Sabile for providing the images in Fig. 1.

\section{References}

AVNET, S., LONGHI, A., SALERNO, M., HALLEEN, J.M., PERUT, F., GRANCHI, D., FERRARI, S., BERTONI, F., GIUNTI, A. and BALDINI, N. (2008). Increased osteoclast activity is associated with aggressiveness of osteosarcoma. Int $\mathrm{J}$ Oncol 33: 1231-1238.

BAPTISTET.A., JAMESA., SARIAM. and OCHIENG J. (2007). Mechano-transduction mediated secretion and uptake of galectin-3 in breast carcinoma cells: Implications in the extracellular functions of the lectin. Exp Cell Res 313: 652-664.

BARTALENA, G., GRIEDER, R., SHARMA, R.I., ZAMBELLI, T., MUFF, R. and SNEDEKER, J.G. (2011). A novel method for assessing adherent single-cell stiffness in tension: design and testing of a substrate-based live cell functional imaging 
device. Biomed Microdevices 13: 291-301.

BJØRNLAND, K., FLATMARK, K., PETTERSEN, S., AAASEN, A.O,. FODSTAD, O. and MAELANDSMO, G.M. (2005). Matrix metalloproteinases participate in osteosarcoma invasion. $J$ Surg Res 127: 151-156.

BONGIORNO, T., KAZLOW, J., MEZENCEV, R., GRIFFITHS, S., OLIVARESNAVARRETE, R., MCDONALD, J.F., SCHWARTZ, Z., BOYAN, B.D., MCDEVITT, T.C. and SULCHEK, T. (2014). Mechanical stiffness as an improved single-cell indicator of osteoblastic human mesenchymal stem cell differentiation. J Biomech 47: 2197-2204.

BOYAN, B.D., LOHMANN, C.H., DEAN, D.D., SYLVIA, V.L., COCHRAN, D.L. and SCHWARTZZ. (2001). Mechanisms Involved in Osteoblast Response to Implant Surface Morphology. Annu Rev Mater Res 31: 357-371.

CHEN, J., WEIHS, D., VAN DIJK, M. and VERMOLEN, F.J. (2018). A phenomenological model for cell and nucleus deformation during cancer metastasis. Biomech Model Mechanobiol 17: 1429-1450.

CILLO, J.E., GASSNER, R., KOEPSEL, R.R. and BUCKLEY, M.J. (2000). Growth factor and cytokine gene expression in mechanically strained human osteoblastlike cells: Implications for distraction osteogenesis. Oral Surgery, Oral Med Oral Pathol Oral Radiol Endodontology 90: 147-154.

DARLING, E.M., TOPEL, M., ZAUSCHER, S., VAIL, T.P. and GUILAK, F. (2008). Viscoelastic properties of human mesenchymally-derived stem cells and primary osteoblasts, chondrocytes, and adipocytes. J Biomech 41: 454-464.

DAVIDSON, P.M., BIGERELLE, M., REITER, G. and ANSELME, K. (2015). Different surface sensing of the cell body and nucleus in healthy primary cells and in a cancerous cell line on nanogrooves. Biointerphases 10: 031004.

DOCHEVA, D., PADULA, D., POPOV, C., MUTSCHLER, W., CLAUSEN-SCHAUMANN, $\mathrm{H}$. and SCHIEKER, M. (2008). Researching into the cellular shape, volume and elasticity of mesenchymal stem cells, osteoblasts and osteosarcoma cells by atomic force microscopy. J Cell Mol Med 12: 537-552.

DOWLING, D.P., MILLER, I.S., ARDHAOUI, M. and GALLAGHER, W.M. (2011). Effect of surface wettability and topography on the adhesion of osteosarcoma cells on plasma-modified polystyrene. J Biomater Appl 26: 327-347.

DUPONT, S., MORSUT, L., ARAGONA, M., ENZO, E., GIULITTI, S., CORDENONSI, M., ZANCONATO, F., LE DIGABEL, J., FORCATO, M., BICCIATO, S., ELVASSORE, N. and PICCOLO, S. (2011). Role of YAPITAZ in mechanotransduction. Nature 474: 179-183.

ENGLER, A.J., SEN, S., SWEENEY, H.L. and DISCHER, D.E. (2006). Matrix Elasticity Directs Stem Cell Lineage Specification. Cell 126: 677-689.

ERMIS, M., AKKAYNAK, D., CHEN, P., DEMIRCI, U. and HASIRCI, V. (2016). A high throughput approach for analysis of cell nuclear deformability at single cell level. Sci Rep 6: 36917.

FROST, H.M. (2003). Bone's mechanostat:A2003 update. Anat Rec275A:1081-1101.

FROST, H.M. (1987). The mechanostat: a proposed pathogenic mechanism of osteoporoses and the bone mass effects of mechanical and nonmechanical agents. Bone Miner 2: 73-85.

GHASSEMI, S., MEACCI, G., LIU, S., GONDARENKO, A.A., MATHUR, A., ROCACUSACHS, P., SHEETZ, M.P. and HONE, J. (2012). Cells test substrate rigidity by local contractions on submicrometer pillars. Proc Natl Acad Sci USA 109: 5328-5333.

GOEDECKE, N., BOLLHALDER, M., BERNET, R., SILVAN, U. and SNEDEKER, J. (2015). Easy and accurate mechano-profiling on micropost arrays. J Vis Exp (105). doi: $10.3791 / 53350$

GORLICK, R. and KHANNA, C. (2010). Osteosarcoma. JBone Miner Res25: 683-691.

HAN Y., COWIN S.C., SCHAFFLER M.B. and WEINBAUM S. (2004). Mechanotransduction and strain amplification in osteocyte cell processes. Proc Natl Acad Sci USA 101: 16689-16694.

HOLENSTEIN,, C.N., HORVATHA., SCHÄR, B., SCHOENENBERGER, A.D., BOLLHALDER, M., GOEDECKE, N., BARTALENA, G., OTTO, O., HERBIG, M., GUCK, J., MÜLLER, D.A., SNEDEKER, J.G. and SILVAN, U. (2019). Force Direction Matters: The Relationship Between Metastatic Potential and In vitro Mechanical Properties of Osteosarcoma Cells. Mol Biol Cell (in press).

HOLENSTEIN, C.N., SILVAN, U. and SNEDEKER, J.G. (2017). High-resolution traction force microscopy on small focal adhesions - improved accuracy through optimal marker distribution and optical flow tracking. Sci Rep 7: 41633.

IACOBINI C., FANTAUZZI C.B., PUGLIESE G. and MENINI S. (2017). Role of Galectin-3 in Bone Cell Differentiation, Bone Pathophysiology and Vascular
Osteogenesis. Int J Mol Sci 18(11). pii: E2481.

IKEGAME, M., ISHIBASHI, O., YOSHIZAWA, T., SHIMOMURA, J., KOMORI, T., OZAWA, H. and KAWASHIMA, H. (2001). Tensile Stress Induces Bone Morphogenetic Protein 4 in Preosteoblastic and Fibroblastic Cells, Which Later Differentiate into Osteoblasts Leading to Osteogenesis in the Mouse Calvariae in Organ Culture. J Bone Miner Res 16: 24-32.

JABBARI, E., SARVESTANI, S.K., DANESHIAN, L. and MOEINZADEH, S. (2015) Optimum 3D Matrix Stiffness for Maintenance of Cancer Stem Cells Is Dependent on Tissue Origin of Cancer Cells Ed. AJ Engler. PLoS One 10: e0132377.

JESSOP, H.L., RAWLINSON, S.C.F., PITSILLIDES, A.A. and LANYON, L.E. (2002) Mechanical strain and fluid movement both activate extracellular regulated kinase (ERK) in osteoblast-like cells but via different signaling pathways. Bone31:186-194.

JIRKA, I., VANDROVCOVÁ, M., PLŠEK, J., BOUŠA, M., BRABEC, L., DRAGOUNOVÁ, H. and BAČÁKOVÁ, L. (2017). Interaction of human osteoblast-like Saos-2 cells with stainless steel coated by silicalite-1 films. Mater Sci Eng C 76: 775-781.

JO, V.Y. and FLETCHER, C.D.M. (2014). WHO classification of soft tissue tumours: an update based on the 2013 (4th) edition. Pathology 46: 95-104.

KAPUR, S., BAYLINK, D.J. and LAU, K.-H.W. (2003). Fluid flow shear stress stimulates human osteoblast proliferation and differentiation through multiple interacting and competing signal transduction pathways. Bone 32: 241-251.

KASPAR, D., SEIDL, W., NEIDLINGER-WILKE, C. and CLAES, L. (2000). In vitro effects of dynamic strain on the proliferative and metabolic activity of human osteoblasts. J Musculoskelet Neuronal Interact 1: 161-164.

KRANING-RUSH, C.M., CALIFANO, J.P. and REINHART-KING, C.A. (2012). Cellular traction stresses increase with increasing metastatic potential. PLOS One 7: e32572-e32572.

LENHERT, S., MEIER, M.-B., MEYER, U., CHI, L. and WIESMANN, H.P. (2005) Osteoblast alignment, elongation and migration on grooved polystyrene surfaces patterned by Langmuir-Blodgett lithography. Biomaterials 26: $563-570$.

LINCKS, J., BOYAN, B.D., BLANCHARD, C.R., LOHMANN, C.H., LIU, Y., COCHRAN, D.L., DEAN, D.D. and SCHWARTZ, Z. (1998). Response of MG63 osteoblastlike cells to titanium and titanium alloy is dependent on surface roughness and composition. Biomaterials 19: 2219-32.

LOHMANN, C.H., BONEWALD, L.F., SISK, M.A., SYLVIA, V.L., COCHRAN, D.L., DEAN, D.D., BOYAN, B.D. and SCHWARTZ, Z. (2000). Maturation State Determines the Response of Osteogenic Cells to Surface Roughness and 1,25-Dihydroxyvitamin D3. J Bone Miner Res 15: 1169-1180.

LU, P., WEAVER, V.M. and WERB, Z. (2012). The extracellular matrix: a dynamic niche in cancer progression. J Cell Biol 196: 395-406.

LÜTHEN, F., LANGE, R., BECKER, P., RYCHLY, J., BECK, U. and NEBE, J.G.B. (2005). The influence of surface roughness of titanium on $\beta 1$ - and $\beta 3$-integrin adhesion and the organization of fibronectin in human osteoblastic cells. Biomaterials 26: 2423-2440.

MARTIN, J.W., ZIELENSKA, M., STEIN, G.S., VAN WIJNEN, A.J. and SQUIRE, J.A (2011). The Role of RUNX2 in Osteosarcoma Oncogenesis. Sarcoma 2011:1-13.

MARTIN, J.Y., SCHWARTZ, Z., HUMMERT, T.W., SCHRAUB, D.M., SIMPSON, J., LANKFORD, J., DEAN, D.D., COCHRAN, D.L. and BOYAN, B.D. (1995). Effect of titanium surface roughness on proliferation, differentiation, and protein synthesis of human osteoblast-like cells (MG63). J Biomed Mater Res 29: 389-401.

MARTINCORENA, I., RAINE, K.M., GERSTUNG, M., DAWSON, K.J., HAASE, K., VAN LOO, P., DAVIES, H., STRATTON, M.R. and CAMPBELL, P.J. (2017). Universal Patterns of Selection in Cancer and Somatic Tissues. Cell 171: 1029-1041.e21.

MARTURANO-KRUIK, A., VILLASANTE, A., YAEGER, K., AMBATI, S.R., CHRAMIEC, A., RAIMONDI, M.T. and VUNJAK-NOVAKOVIC, G. (2018). Biomechanical regulation of drug sensitivity in an engineered model of human tumor. Biomaterials 150: 150-161.

MARTURANO-KRUIK, A., YEAGER, K., BACH, D., VILLASANTE, A., CIMETTA, E. and VUNJAK-NOVAKOVIC, G. (2015). Mimicking biophysical stimuli within bone tumor microenvironment. Conf Proc Annu Int Conf IEEE Eng Med Biol Soc IEEE Eng Med Biol Soc Annu Conf 2015: 3561-4.

MAUPIN K.A., WEAVER K., BERGSMAA., CHRISTIE C., ZHONG Z.A., YANG T. and WILLIAMS B.O. (2018). Enhanced cortical bone expansion in Lgals3-deficient mice during aging. Bone Res 6: 7 .

MCALLISTER, T.N. and FRANGOS, JA. (1999). Steady and transient fluid shear stress stimulate $\mathrm{NO}$ release in osteoblasts through distinct biochemical pathways. J Bone Miner Res 14: 930-6. 
MIRABELLO, L., TROISI, R.J. and SAVAGE, S.A. (2009). Osteosarcoma incidence and survival rates from 1973 to 2004. Cancer 115: 1531-1543.

MUTSAERS, A.J. and WALKLEY, C.R. (2014). Cells of origin in osteosarcoma: Mesenchymal stem cells or osteoblast committed cells? Bone 62: 56-63.

MYLONA, E., DAILIANA, Z.H., TREPAT, X and LAGOUDAKIS, M.G. (2008). Substrate rigidity dictates phenotype, survival, and mechanics of primary human osteosarcoma cells. Eur Symp Biomed Eng 1:4.

NORTHCOTT, J.M., DEAN, I.S., MOUW, J.K. and WEAVER, V.M. (2018). Feeling Stress: The Mechanics of Cancer Progression and Aggression. Front Cell Dev Biol 6: 17.

OTTAVIANI G. and JAFFE N. (2009). The Epidemiology of Osteosarcoma. Cancer Treat Res. 152: 3-13. doi: 10.1007/978-1-4419-0284-9_1

OtTO, O., ROSENDAHL, P., MIETKE, A., GOlFIER, S., HEROLD, C., KLAUE, D., GIRARDO, S., PAGLIARA, S., EKPENYONG, A., JACOBI, A., WOBUS, M., TÖPFNER, N., KEYSER, U.F., MANSFELD, J., FISCHER-FRIEDRICH, E. and GUCK, J. (2015). Real-time deformability cytometry: on-the-fly cell mechanical phenotyping. Nat Methods 12: 199-202.

OZAWA, H., IMAMURA, K., ABE, E., TAKAHASHI, N., HIRAIDE, T., SHIBASAKI, Y., FUKUHARA, T. and SUDA, T. (1990). Effect of a continuously applied compressive pressure on mouse osteoblast-like cells (MC3T3-E1) in vitro. J Cell Physiol 142: $177-185$.

PAK, I., KANTHILAL, M. and DARLING, E. (2015). The Role of Cellular Mechanical Properties in Microenvironment-Dependent Behavior. Biophys J 108: 141a.

PAVALKO, F.M., CHEN, N.X., TURNER, C.H., BURR, D.B., ATKINSON, S., HSIEH, Y.F., QIU, J. and DUNCAN, R.L. (1998). Fluid shear-induced mechanical signaling in MC3T3-E1 osteoblasts requires cytoskeleton-integrin interactions. Am J Physiol 275: C1591-601.

POELLMANN, M.J., ESTRADA, J.B., BOUDOU, T., BERENT, Z.T., FRANCK, C. and WAGONER JOHNSON, A.J. (2015). Differences in Morphology and Traction Generation of Cell Lines Representing Different Stages of Osteogenesis. J Biomech Eng 137: 124503.

PONIK, S.M., TRIPLETT, J.W. and PAVALKO, F.M. (2007). Osteoblasts and osteocytes respond differently to oscillatory and unidirectional fluid flow profiles. J Cell Biochem 100: 794-807.

RAZAFIARISON, T., HOLENSTEIN, C.N., STAUBER, T., JOVIC, M., VERTUDES, E., LOPARIC, M., KAWECKI, M., BERNARD, L., SILVAN, U. and SNEDEKER, J.G. (2018). Biomaterial surface energy-driven ligand assembly strongly regulates stem cell mechanosensitivity and fate on very soft substrates. Proc Natl Acad Sci USA 115: 201704543.

RAZAFIARISON, T., SILVAN, U., MEIER, D. and SNEDEKER, J.G. (2016). SurfaceDriven Collagen Self-Assembly Affects Early Osteogenic Stem Cell Signaling. Adv Healthc Mater 5(12): 1481-1492.

ROSS, J.A., SEVERSON, R.K., SWENSEN, A.R., POLLOCK, B.H., GURNEY, J.G. and ROBISON, L.L. (1999). Seasonal variations in the diagnosis of childhood cancer in the United States. Br J Cancer 81: 549-553.

SHEN, X., GENG, Y., LIU, P., HUANG, X., LI, S., LIU, C., ZHOU, Z. and XU, P. (2017). Magnitude-dependent response of osteoblasts regulated by compressive stress.
Sci Rep 7: 44925.

SHIN, D. and ATHANASIOU, K. (1999). Cytoindentation for obtaining cell biomechanical properties. J Orthop Res 17: 880-890.

SITTICHOCKECHAIWUT, A., SCUTT, A.M., RYAN, A.J., BONEWALD, L.F. and REILLY, G.C. (2009). Use of rapidly mineralising osteoblasts and short periods of mechanical loading to accelerate matrix maturation in 3D scaffolds. Bone 44: 822-829.

STEFFEY, M.A., GARCIA, T.C., DANIEL, L,. ZWINGENBERGER, A.L. and STOVER, S.M. (2017). Mechanical properties of canine osteosarcoma-affected antebrachia. Vet Surg 46: 539-548.

SWIFT, J., IVANOVSKA, I.L., BUXBOIM, A., HARADA, T., DINGAL, P.C.D.P., PINTER J., PAJEROWSKI, J.D., SPINLER, K.R., SHIN, J.-W., TEWARI, M., REHFELDT, F., SPEICHER, D.W. and DISCHER, D.E. (2013). Nuclear Lamin-A Scales with Tissue Stiffness and Enhances Matrix-Directed Differentiation. Science 341 1240104-1240104.

VERBRUGGEN S.W., VAUGHAN T.J. and MCNAMARA L.M. (2012). Strain amplification in bone mechanobiology: a computational investigation of the in vivo mechanics of osteocytes. J R Soc Interface 9: 2735-2744

VERRECCHIA, F. and RÉDINI, F. (2018). Transforming Growth Factor- $\beta$ Signaling Plays a Pivotal Role in the Interplay Between Osteosarcoma Cells and Their Microenvironment. Front Oncol 8: 133.

VOHRA, S., HENNESSY, K.M., SAWYER, A.A., ZHUO, Y. and BELLIS, S.L. (2008). Comparison of mesenchymal stem cell and osteosarcoma cell adhesion to hydroxyapatite. J Mater Sci Mater Med 19: 3567-3574.

WANG, X., YANG, Y., HU, X., KAWAZOE, N., YANG, Y. and CHEN, G. (2016). Morphological and Mechanical Properties of Osteosarcoma Microenvironment Cells Explored by Atomic Force Microscopy. Anal Sci 32: 1177-1182.

WITTKOWSKE, C., REILLY, G.C., LACROIX, D. and PERRAULT, C.M. (2016). In vitro Bone Cell Models: Impact of Fluid Shear Stress on Bone Formation. Front Bioeng Biotechnol 4: 87.

WU, X.-L., TU, Q., FAURE, G., GALLET, P., KOHLER, C. and BITTENCOURT, M.D.C. (2016). Diagnostic and Prognostic Value of Circulating Tumor Cells in Head and Neck Squamous Cell Carcinoma: a systematic review and meta-analysis. Sci Rep 6: 20210.

XAVIER, M., ROSENDAHL, P., HERBIG, M., KRÄTER, M., SPENCER, D., BORNHÄUSER, M., OREFFO, R.O.C., MORGAN, H., GUCK, J. and OTTO, O. (2016). Mechanical phenotyping of primary human skeletal stem cells in heterogeneous populations by real-time deformability cytometry. Integr Biol 8: 616-623.

YAN, Y., GONG, Y., GUO, Y., LV, Q., GUO, C., ZHUANG, Y., ZHANG, Y., LI, R. and ZHANG, X. (2012). Mechanical Strain Regulates Osteoblast Proliferation through Integrin-Mediated ERK Activation Ed. G Pintus. PLoS One 7: e35709.

ZHANG, G., FAN, N., LV, X., LIU, Y., GUO, J., YANG, L., PENG, B. and JIANG, H. (2017). Investigation of the Mechanical Properties of the Human Osteosarcoma Cell at Different Cell Cycle Stages. Micromachines 8: 89.

ZHOU X., JING J., PENG J., MAO W., ZHENG Y., WANG D., WANG X., LIU Z. and ZHANG X. (2014). Expression and clinical significance of galectin-3 in osteosarcoma. Gene 546: 403-407. 


\section{Further Related Reading, published previously in the Int. J. Dev. Biol.}

Morphomechanics: goals, basic experiments and models

Lev V. Beloussov and Vassily I. Grabovsky

Int. J. Dev. Biol. (2006) 50: 81-92

https://doi.org/10.1387/ijdb.052056lb

Direct physical formation of anatomical structures by cell traction forces. An interview with Albert Harris Lev Beloussov

Int. J. Dev. Biol. (2006) 50: 93-101

https://doi.org/10.1387/ijdb.052047eh

The dynamic geometry of mass cell movements in animal morphogenesis

Vladimir G. Cherdantsev

Int. J. Dev. Biol. (2006) 50: 169-182

https://doi.org/10.1387/ijdb.052060vc

Morphogenesis, plasticity and irreversibility

Chikara Furusawa and Kunihiko Kaneko

Int. J. Dev. Biol. (2006) 50: 223-232

https://doi.org/10.1387/ijdb.052051cf

Biophysical regulation during cardiac development and application to tissue engineering Sharon Gerecht-Nir, Milica Radisic, Hyoungshin Park, Christopher Cannizzaro, Jan Boublik, Robert Langer and Gordana Vunjak-Novakovic

Int. J. Dev. Biol. (2006) 50: 233-243

https://doi.org/10.1387/ijdb.052041sg

Mechanical control of tissue morphogenesis during embryological development Donald E. Ingber

Int. J. Dev. Biol. (2006) 50: 255-266

https://doi.org/10.1387/ijdb.052044di

Pulling forces acting on Hox gene clusters cause expression collinearity Spyros Papageorgiou

Int. J. Dev. Biol. (2006) 50: 301-308

https://doi.org/10.1387/ijdb.052034sp
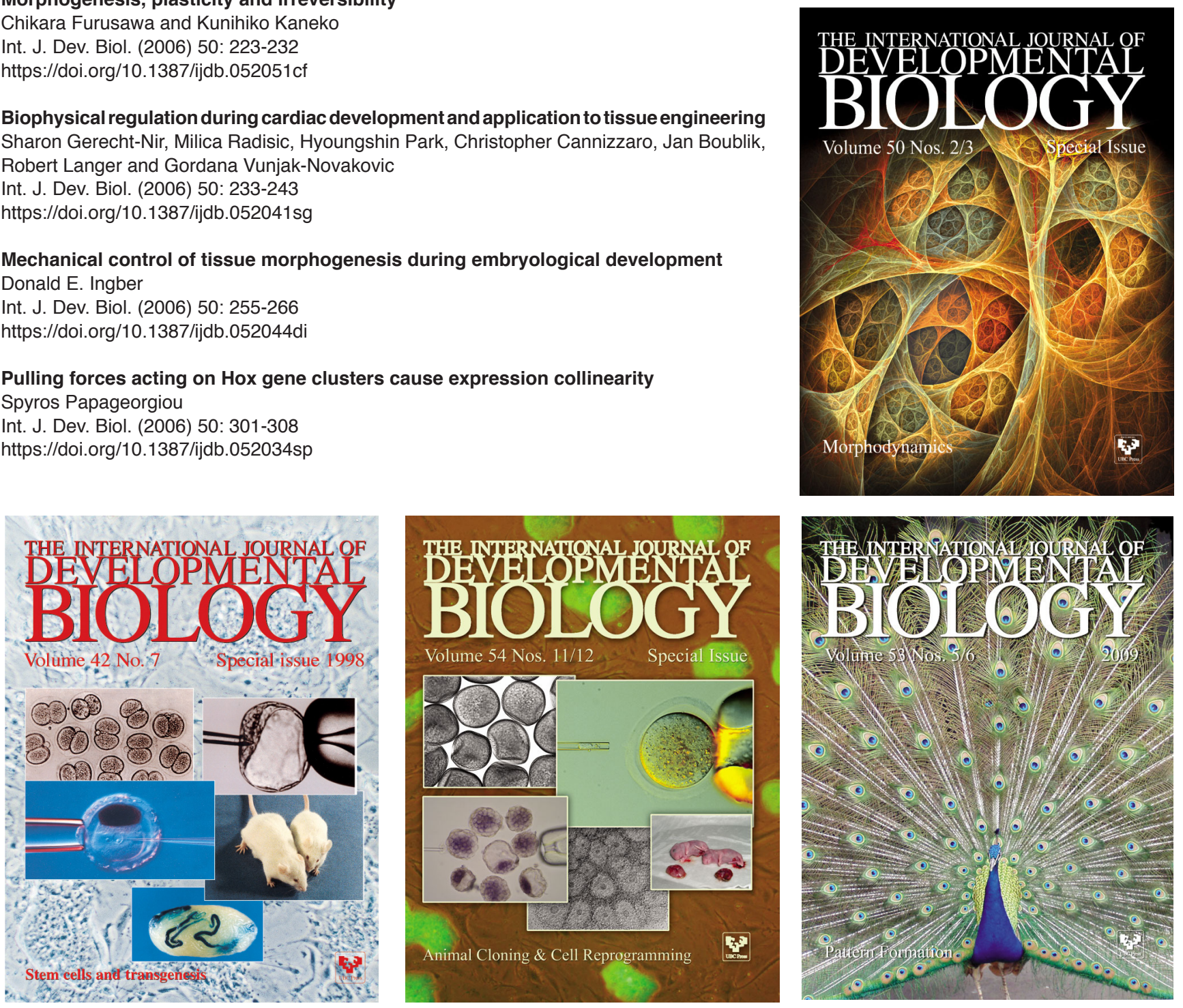